"This document is the Accepted Manuscript version of a Published Work that appeared in final form in Energy \& Fuels, copyright (C) American Chemical Society after peer review and technical editing by the publisher. To access the final edited and published work see http://pubs.acs.org/doi/full/10.1021/acs.energyfuels.6b00327." 


\title{
Comparing active bed materials in a dual fluidized bed biomass gasifier: olivine, bauxite, quartz-sand and ilmenite.
}

\author{
Teresa Berdugo Vilches*, Jelena Marinkovic, Martin Seemann, Henrik Thunman \\ Department of Energy and Environment, Division of Energy Technology, Chalmers University of \\ Technology, SE-41296 Gothenburg, Sweden \\ *E-mail: berdugo@chalmers.se, Tel:+46(0) 317721455
}

\begin{abstract}
Active bed materials are in this work investigated for in-situ gas upgrading of biomass-derived gas.

Previous research on in-situ gas upgrading has focused on assessing gas quality, in terms of the concentrations of tar and permanent gases. Other aspects of fuel conversion, such as char conversion and the impact of oxygen transport on the final gas, are not as well documented in the literature on gasification. In this paper, the overall biomass conversion in a dual fluidized bed biomass gasifier is investigated in the presence of the catalytic material olivine and the alkali-binding material bauxite. The impact of these materials on fuel conversion is described as the combination of four effects, which are induced by the bed material: thermal, catalytic, ash-enhanced catalytic effect, and oxygen transport. Quartz-sand and ilmenite are here used as the reference materials for the thermal and the oxygen transport effects, respectively. Olivine and bauxite, show activity towards tar species compared to quartz-sand. After one week of operation and exposure to biomass ash, the activities of olivine and bauxite towards tar species increase further, and the WGS reaction is catalyzed by both materials. Additionally, bauxite shows stronger ability to increase char conversion than olivine. Under the conditions tested, olivine and bauxite have some degree of oxygen transport capacity, which is between those of quartz-sand and ilmenite. The oxygen transport effect is higher for bauxite than for olivine; nevertheless, the catalytic
\end{abstract}


activities of the materials result in higher yields of $\mathrm{H}_{2}$ than in a similar case with quartz-sand. The implications of the findings for the operation of dual fluidized bed gasifiers are discussed.

\section{KEYWORDS}

Dual fluidized bed, biomass conversion, bauxite, olivine, ilmenite, quartz-sand, solid-phase adsorption, tar, char conversion, oxygen transport, ash 


\section{INTRODUCTION}

Biomass gasification is a key process in the conversion of solid biomass into a product gas that can be used in a variety of applications, e.g. the production of green chemicals and biofuels. Steam gasification enables the production of a $\mathrm{N}_{2}$-free raw gas that consists primarily of $\mathrm{H}_{2}, \mathrm{CO}, \mathrm{CO}_{2}$ and $\mathrm{CH}_{4}$, and it can be implemented in a dual fluidized bed reactor (DFB), which is shown schematically in Fig.1. In the DFB, a hot bed material circulates between two interconnected vessels: a combustor and a steam-fluidized gasifier. The overall reactions that take place within the gasifier are endothermic, whereas those that occur in the combustor are exothermic. The heat released in the combustor side is transported by the bed material to the gasification unit to meet its heat demand.

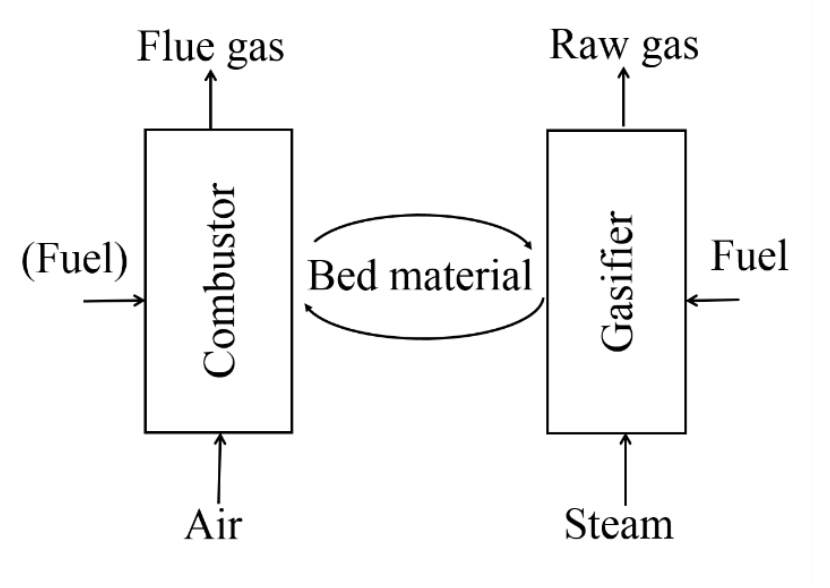

Figure 1. Schematics of a DFB gasifier.

Besides the major components $\left(\mathrm{H}_{2}, \mathrm{CO}, \mathrm{CO}_{2}, \mathrm{CH}_{4}\right)$, the gas that leaves the gasifier also contains low, but significant levels of impurities, such as condensable hydrocarbons (i.e., tar) [1]. In the last few decades, researchers have focused on finding ways to decrease the tar concentration in the product gas, and both primary measures (in-situ) and secondary measures (downstream) have been investigated [2]. Primary measures are attractive since they reduce the need for downstream cleaning equipment, and the energy content of the undesirable species is retained in the product gas [3]. One primary measure for tar reduction 
involves the use of active bed materials and/or additives in the fluidized bed, thereby catalyzing the conversion of tar species into permanent gases in the gasification reactor [3, 4].

A common approach for the investigation of active bed materials has been to test a batch of catalytic particles in a stream of surrogate gas and/or a slipstream of the raw gas from the gasifier (e.g. [5] and [6] respectively). Fewer studies have looked at the use of in-bed catalysts under process conditions (e.g. [7], [8], [9]), and dolomite and olivine are among the most investigated natural materials [3]. Both dolomite and olivine show catalytic activity towards tar species [10], while olivine has greater mechanical strength than dolomite [7]. Owing to its catalytic activity and resistance to attrition, olivine has been applied in existing pilot and demonstration plants, e.g., in the Güssing [11], Milena [12], and GoBiGas [13] gasifiers. The activity of olivine has been partially attributed to its Fe content [11], which has encouraged researchers to use other iron-containing materials, such as Fe/olivine catalysts [14, 15], and ilmenite/sand mixtures [16], as in-bed catalysts.

The tar removal efficiency of a given bed material depends on several factors. A longer operational time typically results in higher activity of the bed material, which can be related to the build-up of ash layers on the bed particles $[11,17]$. The build-up of Ca-rich layers on olivine particles has been suggested to enhance its catalytic activity towards tar and the water-gas shift (WGS) reaction [18]. Additives can also promote the formation of such layers, as demonstrated previously [19] in the Milena gasifier using additives rich in inorganics. In this context, alkali-binding materials, which are commonly used in combustion units, are an interesting option for gasification purposes in that they store the active ash species in the system. For instance, bauxite has been investigated as an alkali-binding material in the context of combustion research and it has been shown to be capable of being regenerated with steam [20]. Alkali species are physically adsorbed to the bauxite material in the combustion unit, whereas they can be released in the gasifier in the presence of steam, thereby influencing the quality of the product gas [21]. 
The debate about in-bed catalysts has to date been dominated by the tar removal efficiency. However, fewer studies have covered the other impacts of an active bed material on biomass conversion under DFB gasification conditions, such as oxygen transport (e.g., [22, 23]), and char conversion (e.g., [7, 9]). In this paper, the focus for in-bed catalysis is extended from tar removal to biomass conversion, which is investigated in the presence of four materials with markedly different properties (i.e., olivine, bauxite, quartz-sand, and ilmenite). The aim of this paper is to compare the impact of the different bed materials on yields of permanent gases, tar and char conversion under conditions relevant to industrial DFB applications. Quartz-sand and ilmenite are, in this work, used as the reference materials for a dominant thermal effect and a dominant oxygen transport effect on fuel conversion, respectively. Since the bed materials are typically exposed to biomass ash in industrial units, the impact of operational time and exposure to biomass ash on fuel conversion is investigated. Additionally, the influence of steam-to-fuel ratio on fuel conversion is assessed. 


\section{FUNDAMENTALS AND DEFINITIONS}

In DFB systems, the bed material acts as: (1) a heat carrier from the combustor to the gasification reactor; (2) a carrier of unconverted char from the gasifier to the combustor; and (3) a carrier of active surfaces/species between the combustor and the gasifier. The two first functions relate to the heat balance of the DFB unit, provided that enough char must be combusted to meet the heat demand of the gasification vessel. For example, for a steam-to-fuel (S/F) ratio of $0.5 \mathrm{~kg} / \mathrm{kg}$ daf fuel, more or less all the char content in the biomass must be combusted, and higher S/F ratio requires additional fuel to be fed to the combustor [24]. The third function of the bed material (i.e., a carrier of active surfaces/species) is relevant to active materials that interact with the fuel or other species in the system; such interactions and their effects on fuel conversion are reviewed below. Figure 2 summarizes four general effects that the bed material can have on fuel conversion: thermal, catalytic, ash-enhanced catalytic effect and oxygen transport effect.

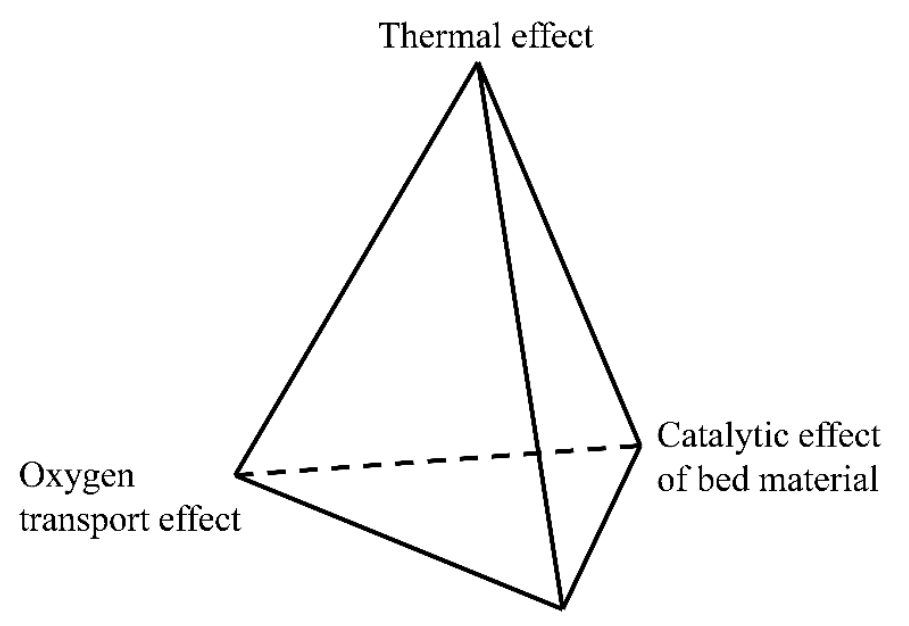

Catalytic effect of ashforming elements

Figure 2. Effects of bed material on fuel conversion.

Thermal effect of the bed material. The thermal effect of bed material on the gasification process refers to the fuel conversion pathway in the presence of chemically inert bed materials; i.e., the fuel conversion 
takes place by the action of heat and the gasification agent. Quartz-sand, which is commonly used in gasification research as a reference material due to its low activity [15, 24], exerts predominantly a thermal effect on fuel conversion.

Catalytic effect of bed material. Catalytic species may be inherent items in the original components of the bed material, for instance Fe in olivine. The availability of the active species can be enhanced by heat treatment, e.g., calcination. Calcined olivine have been found to be more active towards tar species than the untreated olivine, and the higher activity has been attributed to the increased availability of iron on the surfaces of the particles after calcination [11,25]. Rauch et al. also found that untreated olivine reached a level of activity similar to that of calcined olivine after 1 week of operation [11]. The authors concluded that the presence of iron on the particle outer layer played an important role in the activity of the material, although they did not exclude the contributions of other species.

Catalytic effect of ash forming elements. Alkali and alkali earth metals (AAEM), which are commonly present in fuel ash, catalyze tar reactions [2] and steam gasification of char [26]. The most abundant AAEM in woody biomass ash are $\mathrm{K}, \mathrm{Na}$, and $\mathrm{Ca}$. For a given fuel and operating conditions, the catalytic activities of the ash-forming species are dependent upon their interactions with the bed material [27]. If present in the bed material, Si tends to react chemically with the alkali from the fuel to form stable silicates, thereby inhibiting the catalytic activity of the alkali species [26]. Interactions between alkali and Si causes also bed agglomeration by the formation of eutectics with low melting temperature [28]. Alternatively, the alkali species can form active compounds and bond reversibly to the bed material, which in turn increases the activity of the bed [27].

By bonding to the bed material, the active inorganic species are transported throughout the DFB system. For instance, in the presence of sulfur, part of the $\mathrm{K}$ that originate from the fuel forms $\mathrm{K}_{2} \mathrm{SO}_{4}$ in the combustor [29]. The sulfate can be transported by the bed material to the gasifier, where it may become 
catalytically active $\mathrm{KOH}$ or $\mathrm{K}_{2} \mathrm{CO}_{3}$ under reducing conditions [17]. By this conversion route, sulfur enhances the retention of catalytically active forms of potassium in the bed.

Active forms of alkali influence fuel conversion. For instance, in the GoBiGas plant the level of tar in the raw gas was successfully decreased by enriching a bed of olivine with alkali salts (i.e. $\mathrm{K}_{2} \mathrm{CO}_{3}$ ) [13]. Moreover, the rate of steam gasification of char can also be enhanced by the alkali species that are reversibly bound to the bed material. Keller et al. [30] showed that $\mathrm{K}$ in a K-loaded Mn ore was released from the material under Chemical Looping Combustion (CLC) conditions, and it was subsequently adsorbed by the char structure, increasing its reactivity.

Oxygen transport effect. Besides having a catalytic effect, the Fe content of the bed material and the ash-forming species that originate from the biomass are associated to oxygen transport from the combustor to the gasifier through their involvement in redox cycles. For instance, Ca has been shown to participate in a redox cycle in the presence of sulfur by forming $\mathrm{CaS}$ and $\mathrm{CaSO}_{4}$ under reducing and oxidizing conditions, respectively [31]. Oxygen transport has been investigated mainly in the context of CLC. The observed impacts of oxygen transport on fuel conversion are: 1) oxidation of a proportion of the gases derived from the fuel; and 2) enhanced char conversion, as compared with equivalent tests that use inert quartz-sand as bed material [32]. The higher rate of char conversion in the presence of oxygen carriers has been attributed to the lower concentrations of inhibiting species, mainly $\mathrm{H}_{2}$ and tar species, around the char particles $[33,34]$.

Assessment of fuel conversion. The experimental cases which are presented in this paper are compared using the following parameters: gas and tar yields; approach to the WGS and to the methane reforming equilibria; oxygen transport; total carbon conversion; and char conversion. 
The permanent gas $\left(n_{i}\right)$ and tar species $\left(m_{\text {tar }}\right)$ are quantified as the yields per unit of dry-ash-free fuel input ( $\dot{m}_{\text {daf fuel }}$ ) according to Eqs. 1-2. The advantage of using yields rather than concentrations is that the yields relate to the mass balance, and thus, to fuel conversion.

$$
\begin{gathered}
n_{i}=\frac{\dot{n}_{i, \text { hot gas }}}{\dot{m}_{\text {daf fuel }}} \\
m_{\text {tar }}=\frac{\dot{m}_{\text {tar }}}{\dot{m}_{\text {daf fuel }}}
\end{gathered}
$$

The approach to the WGS and methane reforming equilibria $(\delta)$ is calculated according to Table 1 . KWGS and $\mathrm{K}_{\mathrm{CH} 4 \text {,SR }}$ refer to the reaction quotient, and $\mathrm{K}_{\text {eq,i }}$ refer to the equilibrium constant at the operation temperature $[7,8]$.

Table 1. Reaction quotients and the approach to equilibrium for the WGS reaction and steam reforming of methane.

\section{Reaction quotient}

$$
\begin{aligned}
K_{W G S} & =\frac{P_{\mathrm{CO}_{2}} \cdot P_{\mathrm{H}_{2}}}{P_{\mathrm{CO}} \cdot P_{\mathrm{H}_{2} \mathrm{O}}} \\
K_{\mathrm{CH}_{4}, \mathrm{SR}} & =\frac{P_{\mathrm{CO}} \cdot P_{\mathrm{H}_{2}}^{3}}{P_{\mathrm{H}_{2} \mathrm{O}} \cdot P_{\mathrm{CH}_{4}}}
\end{aligned}
$$

Approach to equilibrium

$$
\begin{aligned}
\delta_{W G S} & =\frac{K_{W G S}}{K_{e q, W G S}} \\
\delta_{C H_{4}, S R} & =\frac{K_{C_{4}, S R}}{K_{e q, \mathrm{CH}_{4}, S R}}
\end{aligned}
$$

Oxygen transport $(\Delta \omega)$ is quantified as the oxygen that reacts with the fuel $\left(\Delta \dot{m}_{O}\right)$ per unit of bed material ( $\left.\dot{m}_{\text {bed material }}\right)$, calculated according to Eq.3. Oxygen transport relates solely to the oxygen that originates from the bed material, i.e. any oxygen that originates from steam and air leaks has been subtracted.

$$
\Delta \omega=\frac{\Delta \dot{m}_{O}}{\dot{m}_{\text {bed material }}} \cdot 100
$$

The total carbon conversion from biomass to hot gas $\left(X_{c}\right)$ and char conversion $\left(X_{c h a r}\right)$ are defined by Eqs.4-5 as follows: 


$$
\begin{aligned}
& X_{c}=\frac{\dot{m}_{C, \text { hot gas }}}{\dot{m}_{\text {daf fuel }} \cdot Y_{C, \text { fuel }}} \\
& X_{\text {char }}=\frac{\dot{m}_{\text {daf fuel }} \cdot Y_{\text {Char,fuel }}-\dot{m}_{\text {char,out }}}{\dot{m}_{\text {daf fuel }} \cdot Y_{\text {Char,fuel }}} \cdot 100
\end{aligned}
$$

where $\dot{m}_{C \text {,hot gas }}$ is the mass flow of carbon that exits the gasifier as hot raw gas. Note that the hot raw gas consists of both the permanent gases (i.e. cold gas) and the condensable species. $Y_{C, \text { fuel }}$ and $Y_{C h a r, f u e l}$ denote the carbon and the char contents in the dry-ash-free fuel, respectively. $\dot{m}_{\text {char out }}$ refers to the mass flow of char leaving the gasifier unconverted. 


\section{EXPERIMENTAL}

Experimental setup. The experiments were carried out in the dual fluidized bed gasifier at Chalmers University of Technology. This gasifier is a bubbling bed, which is coupled to a $12-\mathrm{MW}_{\text {th }}$ circulating fluidized bed (CFB) boiler. A simplified sketch of the system is depicted in Fig. 3. The bed material circulates between the combustor (1) and the gasifier (6) via a cyclone (4) and an intermediate fluidized bed vessel or particle distributor (5). The bed material enters the gasifier by means of a loop seal (7), and, thereafter, it returns to the furnace via a second loop seal (8). Both the loop seals and the gasifier (6-8) are fluidized with steam. Further details of the system can be found elsewhere [24].

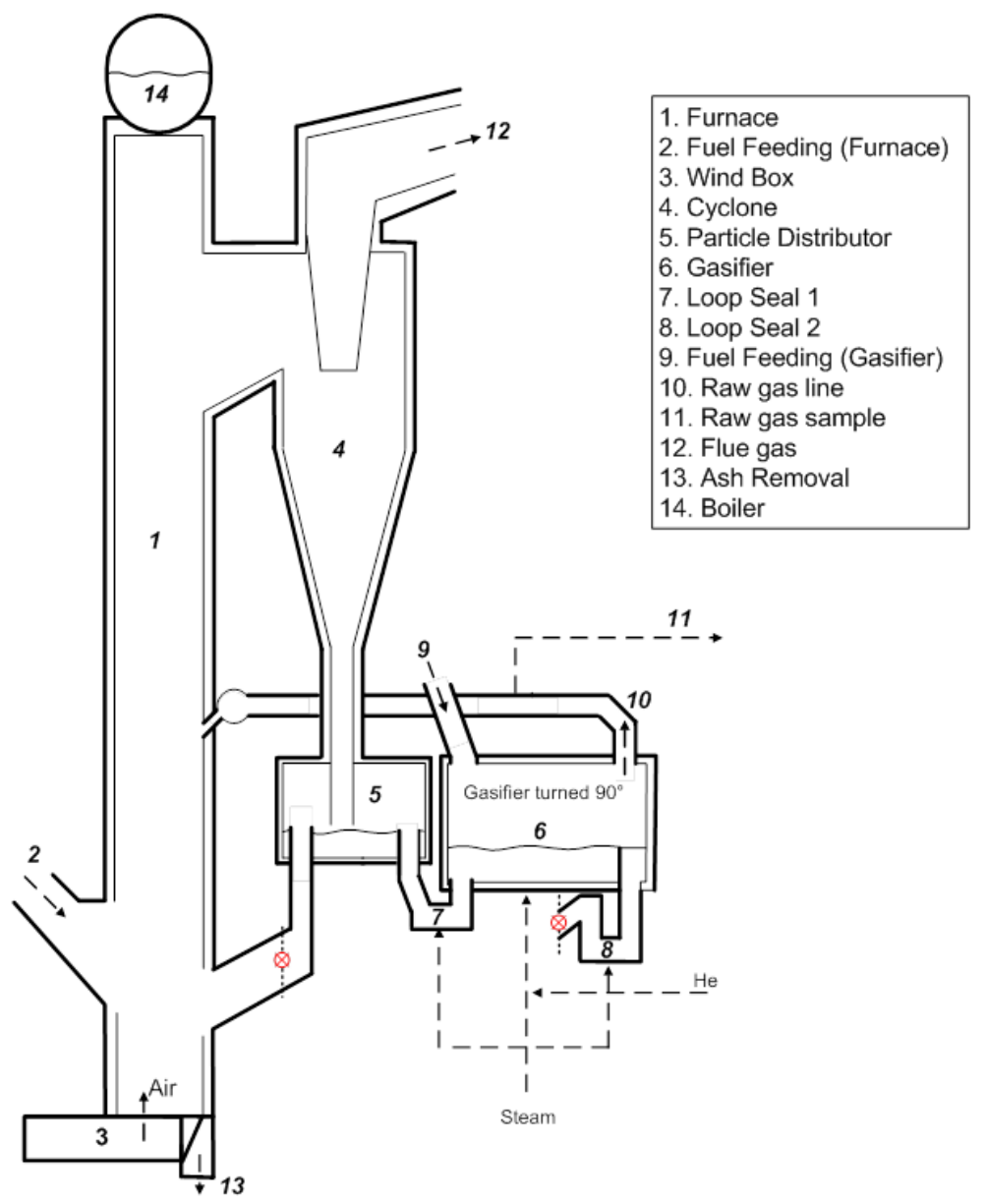

Figure 3. Schematic of the Chalmers DFB system. 
Even though different in appearance, the Chalmers gasifier has similar characteristics to those of commercial DFB units, these are: 1) recirculation of inorganic species; and 2) on-bed fuel feeding system. The GoBiGas plant is here used as a reference of commercial plant, since, up to date, it is the only plant of its kind where biofuels are produced from biomass on a commercial scale. In the GoBiGas plant, the recirculation of inorganics occurs as the fly ash fraction that originates from the gasification reactor is recycled to the combustor. Recirculation of fly ash from the gasifier is a common practice in DFB gasification plants as the fly ash contains significant amount of carbon. Additional recirculation of inorganics takes place as the waste streams generated in the gas cleaning steps return to the combustor for incineration. [35] Furthermore, in the GoBiGas gasifier, the fuel is currently fed onto the surface of the bed despite the original design was an in-bed feeding system. The original in-bed fuel feeding system resulted in operational problems, which were solved by lowering the bed height in the gasifier without negative effect on the gas composition [13]. In the Chalmers gasifier, the recirculation of inorganics is mimicked by returning the raw gas with all its impurities to the combustor side, while the existing on-bed feeding system resembles the current fuel feeding solution at the GoBiGas gasifier.

Gas measurements. A small flow of helium $(\sim 20-30 \mathrm{Ln} / \mathrm{min})$ is used as a tracer gas for quantification of the total dry gas flow per unit of fuel. Helium is added to the fluidization steam, as indicated in Fig.3. Two parallel slipstreams of raw gas $\left(\sim 10 \mathrm{~L}_{\mathrm{n}} / \mathrm{min}\right)$ are continuously sampled from the raw gas line (see 11 in Fig.3). The measurement techniques applied to each slipstream are summarized in Table 2, together with the parameters that were quantified by means of each measurement. 
Table 2. Measurement techniques applied to each slipstream.

\begin{tabular}{|c|c|c|c|c|c|}
\hline & \multirow{2}{*}{$\begin{array}{l}\begin{array}{l}\text { Measurement } \\
\text { technique }\end{array} \\
\text { SPA [36] } \\
\text { He tracing }\end{array}$} & \multirow[b]{2}{*}{$\begin{array}{l}\text { Technical specifications } \\
\text { SPA tubes: with a single layer of amino } \\
\text { propyl-bonded silica or a double } \\
\text { adsorbent layer (amino propyl-bonded } \\
\text { silica and carbon layers) } \\
\text { Equipment: gas chromatographs } \\
\text { equipped with flame ionization detector } \\
\text { (GC-FID). Type BRUKER GC- } 450 \text { and } \\
430 \\
\text { Species assayed: from benzene to } \\
\text { coronene }\end{array}$} & \multicolumn{2}{|c|}{ Parameter quantified } \\
\hline \multirow[t]{2}{*}{ 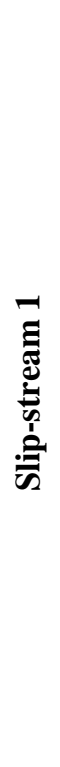 } & Tar yield & & & $\dot{m}_{t a r}$ & (Equation 2) \\
\hline & $\begin{array}{l}\text { Permanent } \\
\text { gas } \\
\text { composition } \\
\text { and yields }\end{array}$ & $\begin{array}{l}\text { Gas analysis } \\
{[24]} \\
\text { He tracing }\end{array}$ & $\begin{array}{l}\text { Equipment: micro-GC Varian Model } \\
\text { CP4900, with Poraplot Q and MS5A } \\
\text { columns. He and Ar as carrier gas, } \\
\text { respectively. } \\
\text { Species assayed: } \mathrm{He}, \mathrm{H}_{2}, \mathrm{CO}, \mathrm{CO}_{2}, \mathrm{CH}_{4} \text {, } \\
\mathrm{C}_{2} \mathrm{H}_{2}, \mathrm{C}_{2} \mathrm{H}_{4}, \mathrm{C}_{2} \mathrm{H}_{6}, \mathrm{C}_{3} \mathrm{H}_{6}, \mathrm{~N}_{2} \text { and } \mathrm{O}_{2}\end{array}$ & $\begin{array}{l}\delta_{W G S} \\
\delta_{C H_{4}, S R} \\
n_{i}\end{array}$ & $\begin{array}{r}\text { (Table 1) } \\
\text { (Equation 1) }\end{array}$ \\
\hline 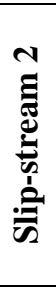 & $\begin{array}{l}\text { Total yield } \\
\text { of CHO in } \\
\text { the hot dry } \\
\text { gas }\end{array}$ & $\begin{array}{l}\text { HTR coupled } \\
\text { to gas analysis } \\
\text { [37] } \\
\text { He tracing }\end{array}$ & $\begin{array}{l}\text { Equipment: micro-GC Varian Model } \\
\text { CP4900. MS5A and Poraplot U } \\
\text { columns. Ar and He as carrier gas, } \\
\text { respectively. } \\
\text { Species assayed: } \mathrm{He}, \mathrm{H}_{2}, \mathrm{CO}, \mathrm{CO}_{2}, \mathrm{CH}_{4} \text {, } \\
\mathrm{C}_{2} \mathrm{H}_{2}, \mathrm{C}_{2} \mathrm{H}_{4}, \mathrm{C}_{2} \mathrm{H}_{6}, \mathrm{C}_{3} \mathrm{H}_{6}, \mathrm{~N}_{2} \text { and } \mathrm{O}_{2}\end{array}$ & $\begin{array}{l}\Delta \omega \\
X_{c} \\
X_{\text {char }}\end{array}$ & (Equation 3-5) \\
\hline
\end{tabular}

Slipstream 1 was used for tar sampling and permanent gas analysis. Tar samples were acquired according to the solid-phase adsorption (SPA) method as described in [36]. At least three samples were obtained for each experimental case, and the results presented are the average value of these three samples. The SPA tubes for the bauxite cases contained a single layer of amino propyl-bonded silica, and resulted in a limited adsorption of BTX compounds. In the other cases, the tar sampling method was improved by using SPA tubes that contained two adsorbent layer (i.e., an amino propyl-bonded silica layer and a carbon layer). Samples that were acquired using SPA tubes with two adsorbent layers resulted in 7-11 fold higher adsorption of BTX compounds than samples that were acquired with SPA tubes that contained a single layer of amino propyl-bonded silica. To ensure that the SPA measurements can be compared among cases, 
the SPA results are presented here as SPA-measurable tar excluding BTX. Additionally, the BTX species are shown when available, i.e. all cases except bauxite.

Downstream of the SPA sampling port, the slipstream 1 is cooled down, filtered, and analyzed by gas chromatography, to quantify the permanent gas components. A basic description of the gas measurement system is provided in Table 2, and further details about the calculations can be found elsewhere [24].

The second slipstream is led to a high-temperature reactor (HTR), which enables quantification of the total $\mathrm{C}, \mathrm{H}$ and $\mathrm{O}$ in the hot dry gas. In the $\mathrm{HTR}$, the hot raw gas is heated to $1700^{\circ} \mathrm{C}$ and all the hydrocarbons are decomposed into $\mathrm{CO}_{2}, \mathrm{CO}$, and $\mathrm{H}_{2}$, which are easily measured by gas-chromatography. By a mass balance throughout the HTR, the elemental flows of $\mathrm{CHO}$ that exit the gasifier as dry hot gas were determined. For a complete description of the configuration of the HTR and the detailed mass balance calculations the reader is referred to [37].

The HTR measurement was not available for the experiments carried out on the first day of operation, and for the olivine case after 1 week of operation, as detailed in Table 5. For the olivine case after 1 week of operation, the total elemental yields of $\mathrm{CHO}$ in the hot dry gas were instead estimated by means of the permanent gas and the SPA-tar yields. This calculation underestimates the carbon conversion and oxygen transport due to the existence of undetectable condensable species [38], which are not accounted for. However, the estimation was considered appropriate as the SPA tubes that were used for the olivine case had high level of adsorption of lighter species (i.e. BTX), which are otherwise not detected.

For the quantification of the reaction quotient, the content of steam of the wet raw gas was estimated indirectly by the molar balance of water throughout the gasifier (Eq. 6); where $\dot{n}_{H_{2} O \text {,input }}$ and $\dot{n}_{H_{2} \text { O,fuel }}$ are the molar flows of water entering the gasifier as steam flow and as fuel moisture, respectively. The third term in Eq. (6) subtracts the estimated steam that has participated in reactions with 
the fuel, where $\dot{n}_{H, h d g}$ and $\dot{n}_{H, c h a r}$ out are the molar flows of hydrogen leaving the gasifier as hot dry gas and with the unconverted char. $\dot{n}_{H, f u e l}$ is the molar flow of hydrogen as dry fuel input.

$$
\begin{gathered}
\dot{n}_{H_{2} O, h w g}=\dot{n}_{H_{2} O, \text { input }}+\dot{n}_{H_{2} O, f u e l}-\left(\dot{n}_{H, h d g}+\dot{n}_{H, \text { char out }}\right. \\
\left.-\dot{n}_{H, \text { fuel }}\right) / 2
\end{gathered}
$$

In the absence of HTR measurement, the molar flow of elemental hydrogen as hot dry gas $\left(\dot{n}_{H, h d g}\right)$ was estimated as the sum of molar flows of elemental hydrogen with the permanent gas and the SPA-measurable species.

Bed materials. The investigated bed materials were: quartz-sand, olivine, bauxite, and ilmenite. The density, mean particle size, and fluidization properties of the materials tested are summarized in Table 3, and their chemical compositions are detailed in Table 4. All materials were fluidized with similar superficial gas velocities, and within the bubbling regime. Quartz-sand, olivine, and bauxite were operated at similar fluidization numbers, whereas the fluidization number was larger for ilmenite due to its smaller size compared to the other materials

\begin{tabular}{|c|c|c|c|c|}
\hline & Quartz sand & Olivine & Bauxite & Ilmenite \\
\hline Particle density $\left(\mathrm{kg} / \mathrm{m}^{3}\right)$ & 2650 & 3300 & 3000 & 4200 \\
\hline$d_{p}(\mu m)$ & 316 & 288 & 305 & 195 \\
\hline Minimum fluidization velocity ${ }^{\mathrm{a}}, \mathrm{u}_{\mathrm{mf}}(\mathrm{m} / \mathrm{s})$ & 0.04 & 0.05 & 0.05 & 0.03 \\
\hline Terminal velocity ${ }^{\mathrm{a}}, \mathbf{u}_{\mathrm{t}}(\mathrm{m} / \mathrm{s})$ & 2.7 & 2.8 & 2.8 & 1.8 \\
\hline Range of fluidization number ${ }^{\mathrm{a}}, \mathrm{u}_{0} / \mathrm{u}_{\mathrm{mf}}$ & $2.8-4.1$ & $2.4-6.3$ & $2.7-4.0$ & $5.6-10.4$ \\
\hline
\end{tabular}

Table 3. Physical and fluidization properties of the materials tested.

${ }^{a}$ Steam at the average bed temperature 
Table 4. Chemical compositions (\%w/w) of the bed materials tested.

\begin{tabular}{|c|c|c|c|c|}
\hline & $\begin{array}{l}\text { Quartz } \\
\text { sand }\end{array}$ & Olivine & Bauxite & Ilmenite \\
\hline $\mathrm{SiO}_{2}$ & 99.2 & 41.7 & 6.50 & 0.40 \\
\hline $\mathrm{Al}_{2} \mathrm{O}_{3}$ & 0.17 & 0.46 & 88.50 & 0.35 \\
\hline $\mathrm{Fe}_{2} \mathrm{O}_{3}$ & 0.054 & 7.4 & 1.10 & 35.0 \\
\hline $\mathbf{T i}_{2} \mathrm{O}$ & & & 3.0 & 51.0 \\
\hline $\mathrm{MgO}$ & & 49.6 & & 1.00 \\
\hline $\mathrm{Cr}_{2} \mathrm{O}_{3}$ & & 0.31 & & 0.30 \\
\hline $\mathrm{NiO}$ & & 0.32 & & \\
\hline $\mathrm{MnO}_{2}$ & & & & 1.30 \\
\hline $\mathrm{V}_{2} \mathrm{O}_{5}$ & & & & 0.23 \\
\hline
\end{tabular}

Biomass fuel. The gasifier was fed with wood pellets with the composition shown in Table 5. The elemental analysis of the fuel was performed by the Technical Research Institute of Sweden, using the standard methods listed in the table. The moisture content was measured by gravimetric analyses of the wet fuel and of the dry fuel after 24 hours at $105^{\circ} \mathrm{C}$. The yield of char was determined by thermo-gravimetric analysis (TGA).

Table 5. Composition of the wood pellets used as fuel in the gasifier.

\begin{tabular}{lllllll}
\hline & $\begin{array}{l}\text { Quartz- } \\
\text { sand case }\end{array}$ & $\begin{array}{l}\text { Ilmenite } \\
\text { case }\end{array}$ & $\begin{array}{l}\text { Bauxite } \\
\text { case }\end{array}$ & $\begin{array}{l}\text { Olivine } \\
\text { case }\end{array}$ & $\begin{array}{l}\text { K-loaded } \\
\text { olivine case }\end{array}$ & Analysis \\
\hline C (\% mass, dry) & 50.7 & 50.3 & 50.0 & 50.1 & 50.9 & SS-EN 15104 \\
H (\% mass, dry) & 6.1 & 6.2 & 6.0 & 6.2 & 6.2 & SS-EN 15104 \\
O (\% mass, dry) & 42.7 & 43.2 & 43.0 & 43.0 & 43.0 & By difference \\
Ash (\%mass, dry) & 0.5 & 0.4 & 0.4 & 0.4 & 0.4 & SS-EN 14775 \\
$\begin{array}{l}\text { Char (\% mass, dry) } \\
\text { Moisture (\% mass, as } \\
\text { received) }\end{array}$ & 18.82 & 18.89 & 18.82 & 18.28 & 18.98 & \\
\hline
\end{tabular}

Experimental matrix. The bed materials were exposed to similar operational conditions to ensure that the differences observed with respect to biomass conversion could be attributed to the properties of the bed materials. The gasifier was fluidized with steam, and the fuel flow was similar in all the cases, being equivalent to approximately $1.3-\mathrm{MW}_{\text {th }}$. The experimental matrix consisted of nineteen cases, including tests on the first day and after 1 week of operation, as well as variations of the steam-to-fuel ratio, as summarized in Table 6. Quartz-sand and ilmenite were used as reference materials for the dominant thermal effect and 
dominant oxygen transport effect, respectively. The complete carbon balances for quartz-sand and ilmenite were investigated previously [38], and therefore they are only used here as supporting cases to interpret the results related to olivine and bauxite.

Measurements were conducted with olivine and bauxite as bed materials on the first day of operation, and thereafter on the ninth day for olivine and seventh day for bauxite. For the measurements on Day 1 of operation, the aim was to investigate the catalytic effect of the bed material that could be attributed primarily to its own composition, given that the bed material had at that stage been exposed to biomass for only a short time. The measurements performed after approximately 1 week of operation represent an aggregate of two contributions to the activity of the material: 1) longer exposure to ash-forming elements; and 2) other physical and chemical changes during operation (e.g., surface changes, Fe migration, etc.). In an attempt to elucidate the relative shares of these two contributions, an additional case was investigated, described as $K$ loaded olivine in Table 6.

The $K$-loaded olivine case refers to a separate batch of untreated olivine that was loaded (by means of additives) with inorganic species on the first day of operation. The measurements were carried out 12 hours after the additives were introduced. This was to investigate the impact of ash species on the activity of a material that had been exposed to operational conditions for a short period of time. Two additives were introduced: potassium carbonate $(6 \mathrm{~kg})$ and elemental sulfur $(7 \mathrm{~kg})$, both in solid form. Potassium carbonate was used as a source of K. Sulfur was added to enable the formation of sulfates [17], with the ambition to enhance the retention of $\mathrm{K}$ in the bed.

Different steam-to-fuel ratios (S/F) were applied after 1 week of operation, as the materials at that stage are considered to represent more accurately those present in industrial applications, which implies longer exposure to biomass ash and operational times. The S/F ratio was here modified by changing the flow of fluidization steam, which also influenced the gas-solid mixing [39], as well as the residence times of the gases in the reactor [38]. The reference case with quartz-sand provided the basis to understand the impacts 
of $\mathrm{S} / \mathrm{F}$ ratio and residence time, whereas the differences between the quartz-sand case and the cases with olivine and bauxite could be attributed to the catalytic activities of the materials.

Each experimental case corresponds to approximately 2 hours of operation, which is sufficient time for the system to become stabilized and allows for a minimum of $30 \mathrm{~min}$ of stable gas measurements. In the present work, only the gas and tar measurements are presented. For details about the interaction between biomass ash and bed materials corresponding to these tests the reader is referred to separate investigations [21] [17], in which a full analysis of the bed samples is provided and discussed. 
Table 6. Summary of the experimental matrix and operating conditions.

\begin{tabular}{|c|c|c|c|c|c|c|c|}
\hline Experimental series & Effect investigated & $\begin{array}{l}\text { Fuel flow } \\
(\mathrm{kg} / \mathrm{h})\end{array}$ & $\begin{array}{l}\mathrm{S} / \mathrm{F}(\mathbf{k g} / \mathbf{k g} \\
\text { daf fuel) }\end{array}$ & $\mathbf{T}_{\text {bed, av }}$ & $\begin{array}{l}\mathbf{T}_{\text {raw gas, }} \\
\text { av }\end{array}$ & $\begin{array}{l}\text { Bed } \\
\text { material } \\
\text { flow } \\
\text { (ton/h) }\end{array}$ & HTR \\
\hline Quartz sand-Day 1 & Thermal & 294 & 0.87 & 814 & 740 & 17 & No \\
\hline \multirow{3}{*}{ Quartz sand-After 1 week } & Thermal+AAEM & 295 & 0.75 & 813 & 735 & 10 & Yes \\
\hline & & 294 & 0.87 & 811 & 740 & 10 & Yes \\
\hline & & 295 & 0.98 & 811 & 744 & 10 & Yes \\
\hline Olivine-Day 1 & Catalytic Fe/Mg & 290 & 0.84 & 801 & 724 & 15 & No \\
\hline \multirow[t]{3}{*}{ Olivine-After 1 week } & Catalytic Fe/Mg + AAEM & 299 & 0.84 & 815 & 725 & 12 & No \\
\hline & & 300 & 0.94 & 815 & 735 & 12 & No \\
\hline & & 299 & 1.20 & 808 & 737 & 12 & No \\
\hline \multirow[t]{3}{*}{ K-loaded olivine } & Catalytic $\mathrm{Fe} / \mathrm{Mg}+\mathrm{K}$ & 298 & 0.60 & 808 & 730 & 15 & Yes \\
\hline & & 296 & 0.83 & 804 & 733 & 15 & Yes \\
\hline & & 290 & 1.07 & 802 & 737 & 15 & Yes \\
\hline Bauxite-Day 1 & Catalytic Al & 295 & 0.82 & 823 & 746 & n.a. & No \\
\hline \multirow[t]{3}{*}{ Bauxite-After 1 week } & Catalytic Al+AAEM & 294 & 0.75 & 821 & 743 & 17 & Yes \\
\hline & & 294 & 0.86 & 816 & 743 & 17 & $\mathrm{Ye}$ \\
\hline & & 295 & 0.98 & 816 & 747 & 17 & Yes \\
\hline \multirow[t]{4}{*}{ Ilmenite } & Oxygen transport & 286 & 0.73 & 828 & 757 & 22 & Yes \\
\hline & & 282 & 0.96 & 824 & 755 & 22 & Yes \\
\hline & & 285 & 1.19 & 821 & 762 & 22 & Yes \\
\hline & & 285 & 1.35 & 820 & 763 & 22 & Yes \\
\hline
\end{tabular}


251 Thermal vs. catalytic effect of the bed material. On the first day of operation, the permanent gas compositions derived for the quartz-sand, olivine, and bauxite beds were similar, with some differences in the levels of $\mathrm{H}_{2}$ and $\mathrm{CO}_{2}$ (See Fig.4a). Generally, higher yields of $\mathrm{H}_{2}$ and $\mathrm{CO}_{2}$ were produced with olivine and bauxite compared to the quartz-sand case. The use of olivine resulted in 20\% lower SPAmeasurable tar compared to the quartz-sand case, as shown in Fig.4b, whereas bauxite exhibited the lowest yield of SPA-measurable tar (excluding BTX) of the three materials.

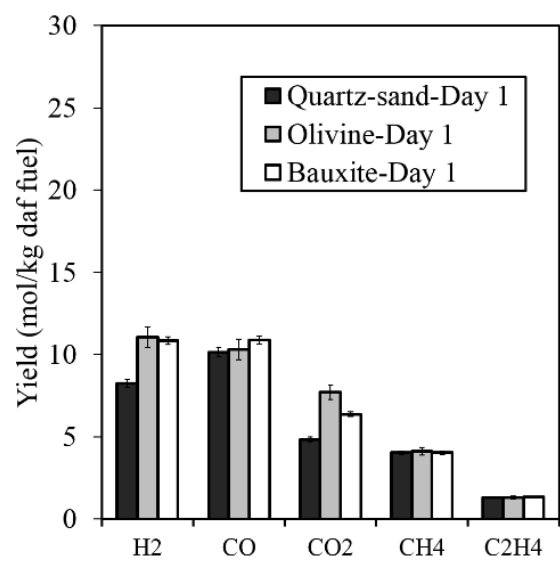

a)

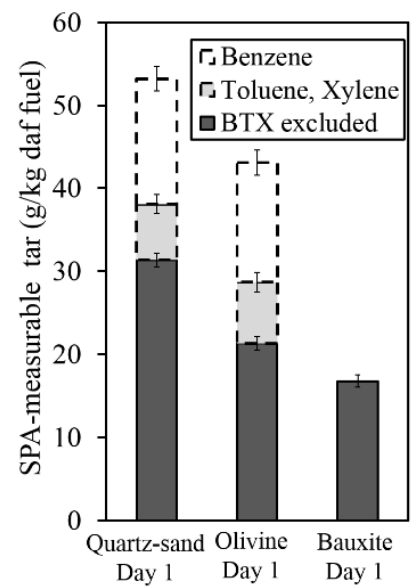

b)

Figure 4. Comparison of a) permanent gas species;

257 b) SPA tar (BTX fraction not available for bauxite), on the first day of operation.

Effect of operational time and exposure to biomass ash. Figure 5 summarizes the approach to the WGS reaction and $\mathrm{CH}_{4}$ reforming equilibria, as defined in Table 1. The extent of the WGS reaction was similar for quartz-sand, olivine and bauxite on the first day of operation. With operational time, the WGS reaction was enhanced significantly for olivine and bauxite. The approach to the $\mathrm{CH}_{4}$ reforming equilibrium is 2 orders of magnitude lower than the approach to the WGS reaction equilibrium. Given the low relevance of the $\mathrm{CH}_{4}$ reforming equilibrium, such a reaction is not discussed further. 


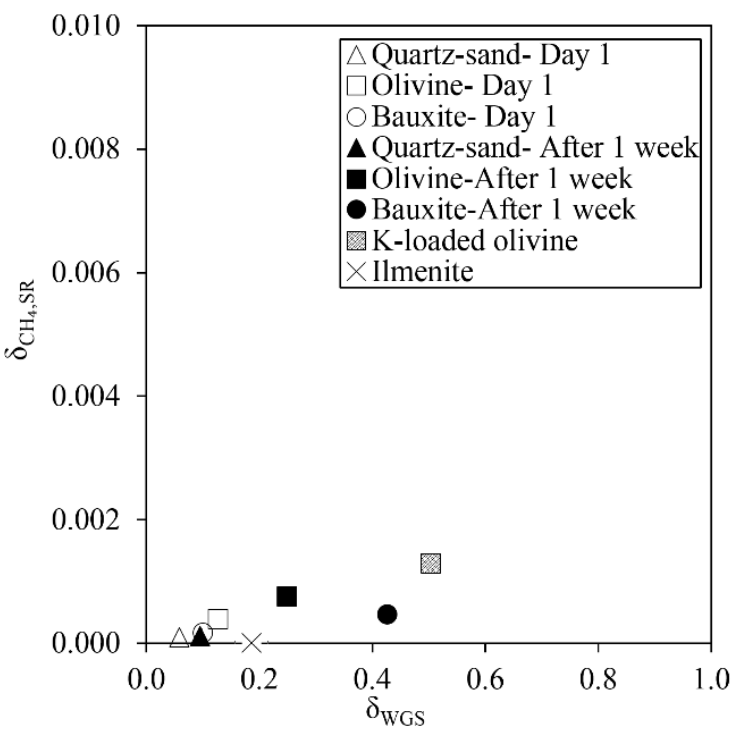

Figure 5. Approach to WGS reaction and $\mathrm{CH}_{4}$ reforming equilibria, at $\mathrm{S} / \mathrm{F}=0.8$. Equilibrium is reached at $\delta=1$.

265 The enhanced WGS reaction contributed to a higher $\mathrm{H}_{2} / \mathrm{CO}$ ratio. Accordingly, a higher $\mathrm{H}_{2} / \mathrm{CO}$ ratio

266 was attained after 1 week of operation, as compared to the $\mathrm{H}_{2} / \mathrm{CO}$ ratio on the first day of operation

267 (Fig.6). The highest $\mathrm{H}_{2} / \mathrm{CO}$ ratio achieved was 2.6, and it corresponds to the K-loaded olivine, which also catalyzed the WGS reaction to the greatest extent (see Fig.5).

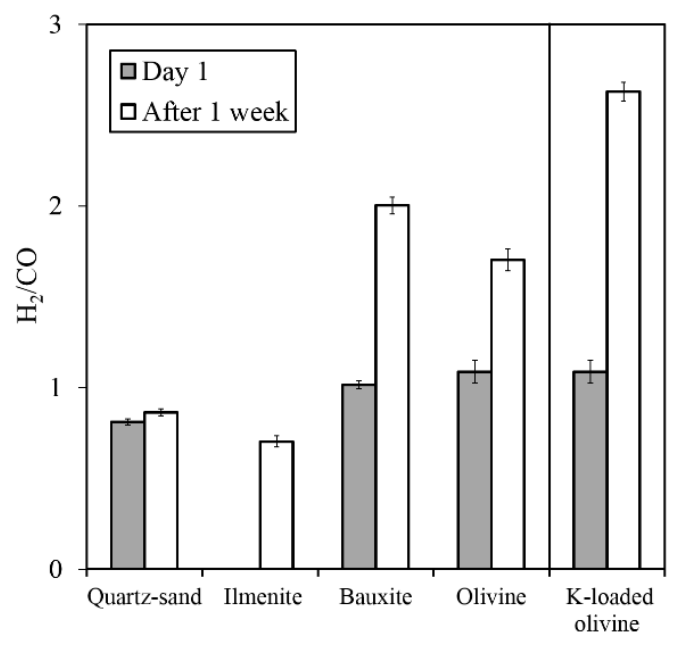

Figure 6. $\mathrm{H}_{2} / \mathrm{CO}$ ratio for all materials tested on the first day of operation and after one week of operation. $\mathrm{S} / \mathrm{F}=0.8$.

269 In similar fashion, the activity towards tar species increased with operational time, although the

270 increase in activity varied among the bed materials used (see Fig.7). The K-loaded olivine gave the

271 largest increase in activity with operational time, i.e., 55\% lower tar after the addition of $\mathrm{K}$ compared 
273 resulted in yields of tar (excluding BTX species) that were $44 \%$ and 57\% lower, respectively, than

274 that of the reference case (quartz-sand).

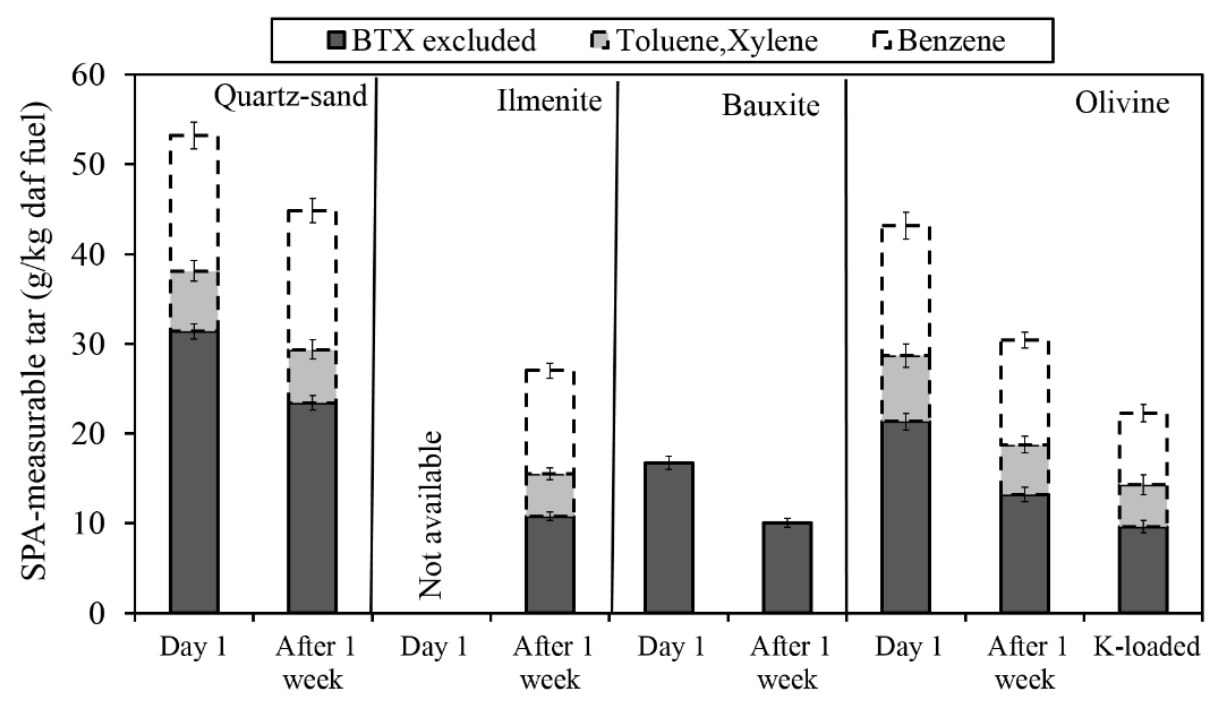

Figure 7. SPA-measurable tar for the different materials on the first day, and after one week of operation; and for the K-loaded olivine after one day of operation. BTX fraction not available for bauxite. S/F ratio=0.8.

276 Oxygen transport effect. All the tested bed materials exhibited some degree of oxygen transport, as

277 shown in Fig.8. After 1 week of operation, the levels of oxygen transport of bauxite and olivine was

278 between those of quartz-sand and ilmenite. Bauxite showed a higher oxygen transport $(0.3 \% \mathrm{w} / \mathrm{w})$ than

279 the two olivine cases $(0.21 \%-0.19 \% \mathrm{w} / \mathrm{w})$. 


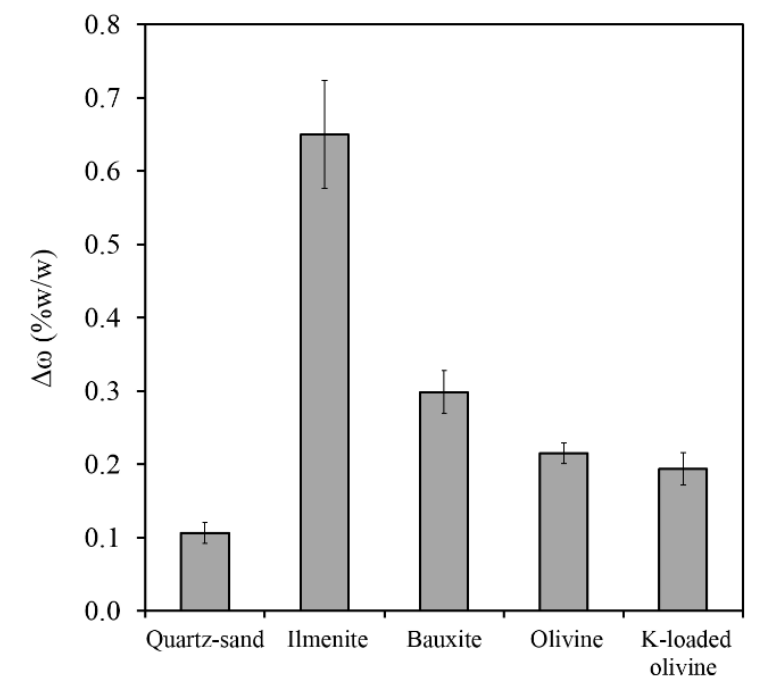

Figure 8. Oxygen transport capacities of the bed materials after 1 week of operation, and for the Kloaded olivine case. S/F ratio 0.8 .

280 Effect of the S/F ratio. The yields of permanent gas species are summarized in Fig.9 as a function of

281 the S/F ratios used for the materials after 1 week of operation. The gas composition for the S/F ratio of

282 zero corresponds to the outcome from a pyrolysis experiment conducted in an inert atmosphere with a

283 similar fuel [24]. Linear trend lines have been added to the figures to improve readability. 


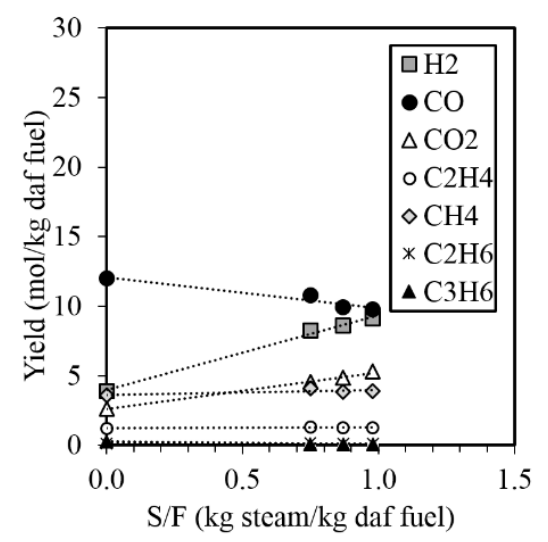

a)

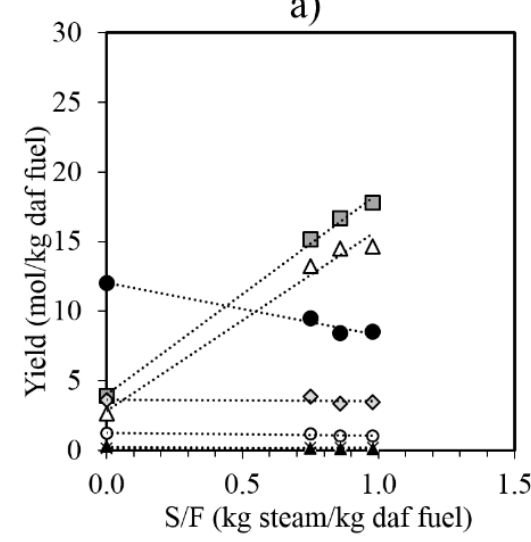

c)

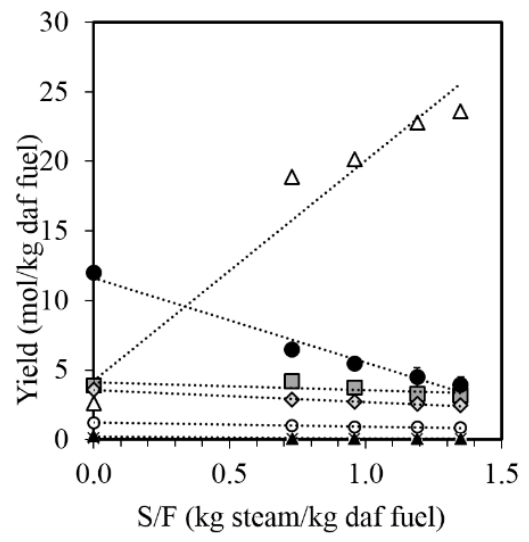

b)

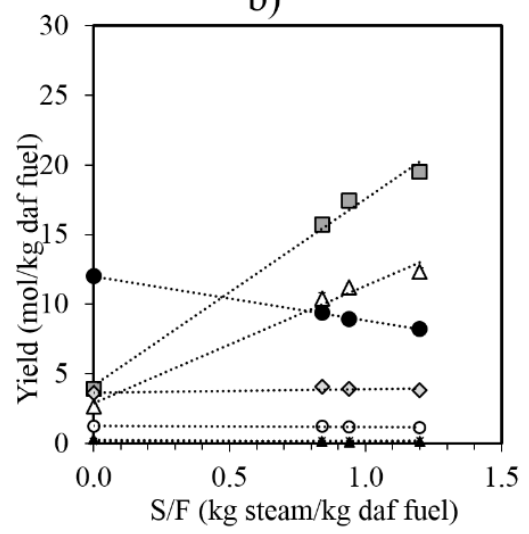

d)

Figure 9. Yields of permanent gas species as a function of the $\mathrm{S} / \mathrm{F}$ ratio for the different bed materials after 1 week of operation: a) quartz-sand reference; $b$ ) Ilmenite reference; c) Bauxite; d) Olivine. Gas yields for $\mathrm{S} / \mathrm{F}=0$ is the result of a pyrolysis experiment in $\mathrm{N}_{2}$ atmosphere reported in [24].

284 The yields of SPA-measurable tar are summarized in Fig.10 as a function of the S/F ratio. The largest 285 component in the BTX group was benzene, which accounts for $62-76 \%$ w/w of the BTX fraction. Both

286 olivine and bauxite yielded significantly lower SPA-measurable tar than the quartz-sand reference case

287 under all the conditions tested. The lowest yields of SPA-measurable tar (excluding BTX) were achieved with bauxite and the K-loaded olivine, which yielded results similar to the ilmenite case. In general, a decrease in SPA-measurable tar was observed with increasing S/F ratio for all the bed materials tested. 


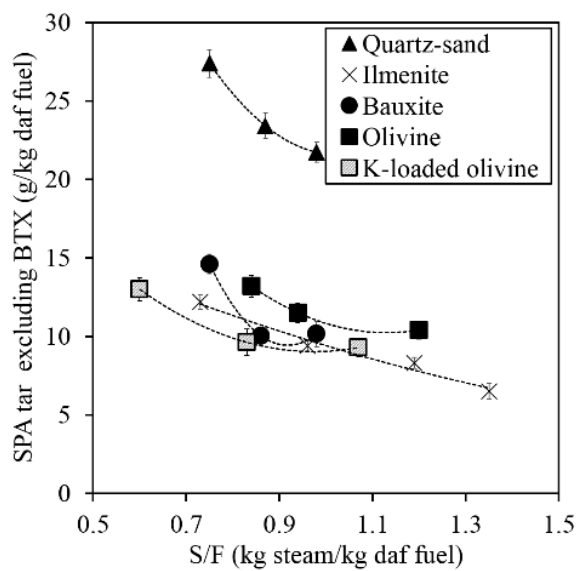

a)

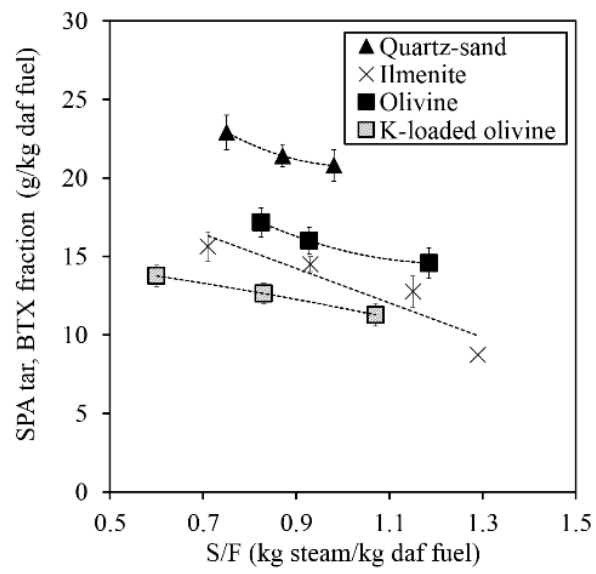

b)

Figure 10. Yield of SPA-measurable tar as a function of S/F ratio. a) BTX fraction excluded; b) BTX fraction (not available for bauxite).

291 The values for the total carbon conversion $X_{c}$ are summarized in Fig.11a as a function of the S/F ratio

292 for the materials after 1 week and the K-loaded olivine. The lower and upper limit of the shaded area in

293 Fig.11a corresponds to the carbon in the volatile fraction of the fuel according to standard TGA

294 measurement (Table 5), and to the pyrolysis experiment of a similar fuel in a fluidized bed reported in

295 [24]. For the K-loaded olivine and bauxite, there is an increase of char conversion as the S/F ratio increased. Under the conditions tested, all the materials resulted in a significantly higher degree of char conversion compared to the reference case with quartz-sand (Fig.11b). Note that the carbon conversion for the olivine case is underestimated as mentioned in the experimental section.

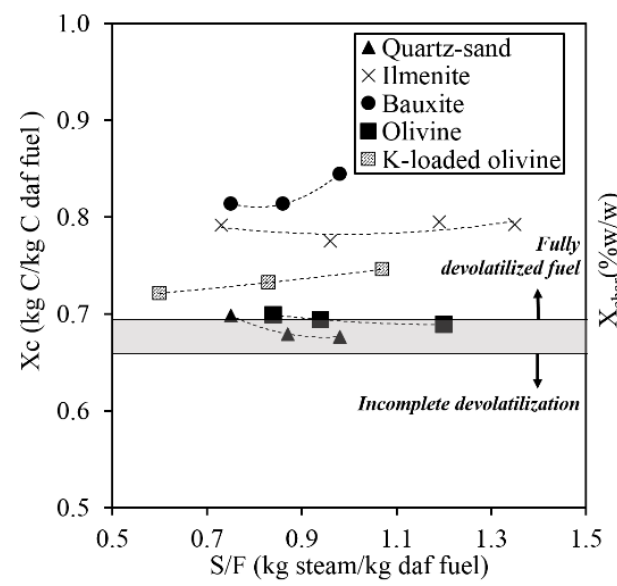

a)

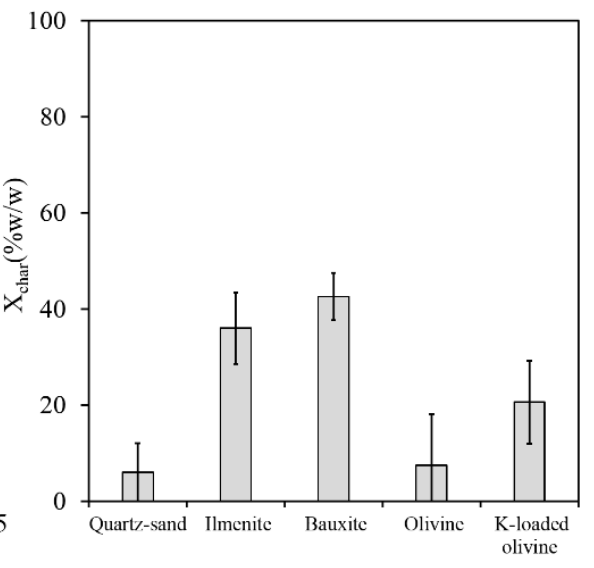

b)

Figure 11. a) Total carbon conversion $\left(X_{c}\right)$ as a function of $S / F$ ratio, b) Char conversion $\left(\mathrm{X}_{\text {char }}\right)$ for all materials tested at $\mathrm{S} / \mathrm{F}$ ratio 0.8 . 


\section{DISCUSSION}

300

301

302

303

304

305

306

308

309

310

311

312

313

314

315

316

317

318

319

320

321

322

323

324

Operating time and, more importantly, exposure to alkali species, exerted the strongest influences on the activities of olivine and bauxite. The higher activity of the bed material after several days of operation can be in part attributed to the accumulation of ash species on the bed material particles, which act as a catalyst for the WGS reaction and tar reactions [17]. The relevance of alkali species became clear with the K-loaded olivine, which outperformed the other materials in terms of tar conversion and catalysis of the WGS equilibrium. After several days of operation, olivine and bauxite increased the $\mathrm{H}_{2} / \mathrm{CO}$ ratio significantly, as compared to the quartz-sand. Therefore, both materials are suitable options for adjusting the $\mathrm{H}_{2} / \mathrm{CO}$ inside the gasifier, which can be desirable for the production of bio-fuels. Furthermore, the observed weak impacts of olivine and bauxite on methane yield (see Fig.5) represents an advantage for bio-SNG production. The enhanced WGS reaction and modest impact on $\mathrm{CH}_{4}$ have also been observed by others [8] and [7] when comparing olivine to quartz-sand.

Oxygen transport typically results in a high yield of $\mathrm{CO}_{2}$, which is coupled to a decrease in the $\mathrm{H}_{2}$ yield if the oxygen transport is the dominant effect (see the ilmenite case in Fig.9b). In the cases of bauxite and olivine, the detrimental effect of oxygen transport on $\mathrm{H}_{2}$ yield was overcompensated by the catalytic activities towards tar and the WGS reaction (compare Fig.9b, $\mathrm{c}$ and d). The weak impact of oxygen transport on gas quality for olivine as the bed material was also highlighted by others [23]. It is noteworthy that while bauxite has a higher oxygen transport capacity than olivine, they generate similar $\mathrm{H}_{2}$ yields under comparable operating conditions (recall Fig.9c and d). This can be explained by the higher char conversion rate in the case of bauxite, which partially compensates for the combusted $\mathrm{H}_{2}$. The product gas, however, was richer in $\mathrm{CO}_{2}$ with bauxite compared with olivine, as the oxygen transport was larger. For both olivine and bauxite, the $\mathrm{H}_{2}$ yield is boosted further by a higher $\mathrm{S} / \mathrm{F}$ ratio. This is in line with enhanced WGS reaction and conversion of hydrocarbons, which is promoted by the improved gas-solid mixing and greater availability of steam. Under the conditions tested, the catalytic materials with oxygen transport capacities $<0.3 \% \mathrm{w} / \mathrm{w}$ did not exert significant detrimental effects on the $\mathrm{H}_{2}$ yield. 
325 Oxygen transport ability is commonly attributed to the Fe in iron-containing materials, such as olivine 326 [22]. However, in the present investigation, the oxygen transport capacity of the materials do not 327 correlate with the iron contents in the original ores. While olivine has a 7-fold higher level of Fe than bauxite (recall Table 4), the oxygen transport capacity of bauxite is greater than that of olivine, as shown in Fig.8. The discrepancy may be explained by two factors: 1) the different availability of accessible iron [11]; and the ash content of the particles, which can contribute to the oxygen transport [31]. The possibility of transporting oxygen by means of the ash species that are bound to the bed particles also explains the oxygen transport for quartz-sand, which does not include oxygen-carrying species in its original composition. Furthermore, the K-loaded olivine had similar oxygen transport ability to the base case of olivine already after 1 day of operation, which also accords with the higher ash load contributing to oxygen transport. In fact, the addition of sulfur to the K-loaded olivine may also have promoted oxygen transport by calcium species, as proposed previously by [31]. Therefore, it appears that not only the Fe content, but also the ash load contributes significantly to the net oxygen transport of the material in DFB systems.

Besides their influence on gas quality, the tested bed materials also significantly affected the degree of char conversion, which was also observed by other authors [7] and [9]. Note that the differences in char conversion among materials (Figure 11b) cannot be explained only by changes in residence time of the fuel in the bed. For instance, higher fluidization velocity and higher bed material flows typically decreases the residence time of the fuel in the gasification reactor [40]. However, the material that was operated at the lowest solids flow in the experimental matrix (i.e. quartz-sand case), yields the lowest char conversion of all the cases investigated, regardless the fluidization velocity. These results points that the active bed materials tested can enhance the char gasification rate significantly. A higher char conversion rate in the gasifier decreases the flow of char from the gasifier to the combustor, which alters the heat balance of the DFB system. This means that additional fuel may have to be introduced into the combustor when switching from quartz-sand to an active material in existing units. Alternatively, the degree of char conversion can be optimized by controlling the residence time of the char in the gasifier. The particular measures to shorten the residence time of the char in the gasifier depend on the gasifier 
design, and they require a good understanding of the fluid dynamics of the reactor, as well as evaluation of their implications for the quality of the raw gas.

The catalytic effect of the bed material on the steam gasification of char can be attributed to two mechanisms: 1) to oxygen transport [33]; and/or 2) the release of catalytic ash elements from the bed material [30]. Although oxygen transport by bauxite is significantly lower than that by ilmenite (recall Fig.8), bauxite yields higher char conversion than ilmenite. The lack of correlation between oxygen transport and char conversion in the present study suggests that there is an additional contribution of releasable catalytic ash-forming elements. The possibility to release alkali species in the gasification unit can also explain the different trends observed for char conversion with different S/F values (Fig.11). Increasing the steam flow can enhance the release of ash species from the bed material, which could then interact with the char, as proposed previously [30]. The impact on char conversion can thus be linked to the ability of the alkali species to be released from the bed material. In the case of quartz-sand, the alkali species are most likely chemically bound to silicon, which cannot be desorbed with steam [26]. Therefore, the trend in the quartz-sand case shown in Fig.11 is in line with the shorter residence time of the fuel in the gasifier as fluidization velocity increases [38]. When alkali species are physically bound to the material, as in the case of bauxite [20], a greater steam flow results in enhanced char conversion, in line with the enhanced desorption of alkali species from the material.

The nature of the interactions between ash species and bed material (i.e., physical or chemical bonds) has also implications for the long term reactivity of the bed material. Reversible bonding of active ashforming elements to the bed particles can result in the loss of active species together with the raw gas, as they are leached out by steam in the gasifier. Loss of active species from the bed can also occur if the ash species in the material react chemically with the gas to form gaseous species, as proposed by [17]. As a result, the bed inventory can lose its activity if the alkali balance of the system is not considered. Strategies to retain the alkali load in the bed include recirculation of ash to the gasifier, cogasification with alkali-rich fuels, and direct addition of alkali species when the reactivity decreases. Controlling the activity of the bed inventory by addition of alkali species is not recommended for high silicon content materials, e.g. quartz-sand, since agglomeration problems would arise. 


\section{SUMMARY AND CONCLUSIONS}

380 The impact of the bed material on biomass conversion was investigated under conditions relevant to industrial DFB gasifiers. Biomass conversion was assessed and compared in the presence of four bed materials with markedly different properties, namely, olivine, bauxite, ilmenite, and quartz-sand. Quartz-sand and ilmenite were used as reference cases for a dominant thermal effect and a dominant oxygen transport effect, respectively. The following conclusions can be derived from the experimental results:

(1) Both bauxite and olivine are suitable in-bed WGS catalysts and are able to double the $\mathrm{H}_{2} / \mathrm{CO}$

(6) Bauxite increases the char gasification rate to a greater extent than olivine, which reflects its ability to release alkali species in a steam environment.

Finally, the strong increases in the activity of bauxite and olivine observed after several days of operation highlight the importance of considering alkali load and treatment (e.g., the 'operating history') 
403 of the material when comparing their performances. Results obtained from tests with alkali-free gases 404 must be interpreted and extrapolated with caution to in-situ applications. The alkali binding/release 405 abilities of bed materials should be considered to exploit their catalytic properties, as well as to maintain 406 their activities over time in industrial units.

\section{SUPPORTING INFORMATION AVAILABLE}

408 The yields of SPA-measurable tar $(\mathrm{g} / \mathrm{kg}$ daf fuel) for the different bed materials applied in the Chalmers 409 DFB gasifier operated at similar bed temperature $\left(815 \pm 15^{\circ} \mathrm{C}\right)$ and various steam-to-fuel ratios are 410 provided in Table $\mathrm{S} 1$ as supporting information.

\section{AUTHOR INFORMATION}

\section{Corresponding Author}

$413 * * *$ Tel:+46(0) 3177214 55, E-mail: berdugo@ chalmers.se

\section{ACKNOWLEDGMENTS}

415 This work was financially supported by the Swedish Gasification Center (SFC) in collaboration with 416 Akademiska Hus, Valmet AB, E.ON AB, Göteborg Energi, and the Swedish Energy Agency. The 417 authors acknowledge Mikael Israelsson and research engineers Jessica Bohwalli, Johannes Öhlin and 418 Rustan Marberg for their support during the experimental campaign. 


\section{REFERENCES}

1. Abdoulmoumine, N., et al., A review on biomass gasification syngas cleanup. Applied Energy, 2015. 155: p. 294-307.

2. Anis, S. and Z.A. Zainal, Tar reduction in biomass producer gas via mechanical, catalytic and thermal methods: A review. Renewable and Sustainable Energy Reviews, 2011. 15(5): p. 2355-2377.

3. Devi, L., K.J. Ptasinski, and F.J.J.G. Janssen, A review of the primary measures for tar elimination in biomass gasification processes. Biomass and Bioenergy, 2003. 24(2): p. 125-140.

4. Sutton, D., B. Kelleher, and J.R.H. Ross, Review of literature on catalysts for biomass gasification. Fuel Processing Technology, 2001. 73(3): p. 155-173.

5. Keller, M., et al., Investigation of Natural and Synthetic Bed Materials for Their Utilization in Chemical Looping Reforming for Tar Elimination in Biomass-Derived Gasification Gas. Energy \& Fuels, 2014. 28(6): p. 3833-3840.

6. Lind, F., M. Seemann, and H. Thunman, Continuous Catalytic Tar Reforming of Biomass Derived Raw Gas with Simultaneous Catalyst Regeneration. Industrial \& Engineering Chemistry Research, 2011. 50(20): p. 11553-11562.

7. Rapagnà, S., et al., Steam-gasification of biomass in a fluidised-bed of olivine particles. Biomass and Bioenergy, 2000. 19(3): p. 187-197.

8. Koppatz, S., C. Pfeifer, and H. Hofbauer, Comparison of the performance behaviour of silica sand and olivine in a dual fluidised bed reactor system for steam gasification of biomass at pilot plant scale. Chemical Engineering Journal, 2011. 175(0): p. 468-483.

9. de Andrés, J.M., A. Narros, and M.E. Rodríguez, Behaviour of dolomite, olivine and alumina as primary catalysts in air-steam gasification of sewage sludge. Fuel, 2011. 90(2): p. 521-527.

10. Corella, J., J.M. Toledo, and R. Padilla, Olivine or Dolomite as In-Bed Additive in Biomass Gasification with Air in a Fluidized Bed: Which Is Better? Energy \& Fuels, 2004. 18(3): p. 713-720.

11. Rauch, R., et al. Comparison of different olivines for biomass steam gasification. in Conference for Science in Thermal and Chemical Biomass Conversion. 2004.

12. Almansa, G.A., et al., ECN System for MEthanation (ESME), in EUBCE 2015 2015: Vienna, Austria

13. Thunman, H., A. Larsson, and M. Hedenskog, Commissioning of the GoBiGas 20MW Bio-methane Plant, in tcbiomass 2015. 2015: Chicago.

14. Virginie, M., et al., Effect of Fe-olivine on the tar content during biomass gasification in a dual fluidized bed. Applied Catalysis B: Environmental, 2012. 121-122(0): p. 214222.

15. Pfeifer, C., S. Koppatz, and H. Hofbauer, Steam gasification of various feedstocks at a dual fluidised bed gasifier: Impacts of operation conditions and bed materials. Biomass Conversion and Biorefinery, 2011. 1(1): p. 39-53.

16. Larsson, A., et al., Using Ilmenite To Reduce the Tar Yield in a Dual Fluidized Bed Gasification System. Energy \& Fuels, 2014. 28(4): p. 2632-2644.

17. Marinkovic, J., et al., Characteristics of olivine as a bed material in an indirect biomass gasifier. Chemical Engineering Journal, 2015. 279: p. 555-566.

18. Kirnbauer, F., et al., The positive effects of bed material coating on tar reduction in a dual fluidized bed gasifier. Fuel, 2012. 95: p. 553-562.

19. Grootjes, A.J., van der Meijden, C.M., Visser, H.J.M., van der Drift, A., Improved Gasifier Availability with Bed Material and Additives, in 21st European Biomass Conference and Exhibition. 2013. p. 407 - 413. 
20. Punjak, W.A., High-temperature interactions of alkali vapors with solids during coal combustion and gasification. Other Information: Thesis (Ph. D.). 1988. Medium: X; Size: Pages: $(310$ p).

21. Marinkovic, J., et al., Impact of biomass ash - bauxite bed interactions on an indirect biomass gasifier. (Recently submitted to Energy \& Fuels), 2016.

22. Lancee, R.J., et al., Chemical looping capabilities of olivine, used as a catalyst in indirect biomass gasification. Applied Catalysis B: Environmental, 2014. 145: p. 216222.

23. S. Koppatz, et al., Investigation of reforming activity and oxygen transfer of olivine in a dual circulating fluidised bed system with regard to biomass gasification, in The 13th International Conference on Fluidization - New Paradigm in Fluidization Engineering. 2010.

24. Larsson, A., et al., Evaluation of Performance of Industrial-Scale Dual Fluidized Bed Gasifiers Using the Chalmers 2-4-MWth Gasifier. Energy \& Fuels, 2013. 27(11).

25. Christodoulou, C., et al., Comparing calcined and un-treated olivine as bed materials for tar reduction in fluidized bed gasification. Fuel Processing Technology, 2014. 124(0): p. 275-285.

26. Nzihou, A., B. Stanmore, and P. Sharrock, A review of catalysts for the gasification of biomass char, with some reference to coal. Energy, 2013. 58(0): p. 305-317.

27. Marinkovic, J., Choice of bed material: a critical parameter in the optimization of dual fluidized bed systems, in Energy and Environment. 2016, Chalmers University of Technology.

28. Elled, A.L., L.E. Åmand, and B.M. Steenari, Composition of agglomerates in fluidized bed reactors for thermochemical conversion of biomass and waste fuels: Experimental data in comparison with predictions by a thermodynamic equilibrium model. Fuel, 2013. 111: p. 696-708.

29. Niu, Y., H. Tan, and S.e. Hui, Ash-related issues during biomass combustion: Alkaliinduced slagging, silicate melt-induced slagging (ash fusion), agglomeration, corrosion, ash utilization, and related countermeasures. Progress in Energy and Combustion Science, 2016. 52: p. 1-61.

30. Keller, M., H. Leion, and T. Mattisson, Mechanisms of Solid Fuel Conversion by Chemical-Looping Combustion (CLC) using Manganese Ore: Catalytic Gasification by Potassium Compounds. Energy Technology, 2013. 1(4): p. 273-282.

31. Pecho, J., et al., Reactive bed materials for improved biomass gasification in a circulating fluidised bed reactor. Chemical Engineering Science, 2008. 63(9): p. $2465-$ 2476.

32. Mendiara, T., et al., Biomass combustion in a CLC system using an iron ore as an oxygen carrier. International Journal of Greenhouse Gas Control, 2013. 19(0): p. 322330.

33. Keller, M., et al., Gasification inhibition in chemical-looping combustion with solid fuels. Combustion and Flame, 2011. 158(3): p. 393-400.

34. Fushimi, C., T. Wada, and A. Tsutsumi, Inhibition of steam gasification of biomass char by hydrogen and tar. Biomass and Bioenergy, 2011. 35(1): p. 179-185.

35. Hedenskog, M., Gasification offorest residues-IRL in a large demonstration scale. The GoBiGas-project. 2014, Göteborg Energi.

36. Israelsson, M., M. Seemann, and H. Thunman, Assessment of the Solid-Phase Adsorption Method for Sampling Biomass-Derived Tar in Industrial Environments. Energy \& Fuels, 2013. 27(12): p. 7569-7578. 
37. Israelsson, M., A. Larsson, and H. Thunman, Online Measurement of Elemental Yields, Oxygen Transport, Condensable Compounds, and Heating Values in Gasification Systems. Energy \& Fuels, 2014. 28(9): p. 5892-5901.

38. Israelsson, M., T. Berdugo Vilches, and H. Thunman, Conversion of Condensable Hydrocarbons in a Dual Fluidized Bed Biomass Gasifier. Energy \& Fuels, 2015.

39. Berdugo Vilches, T. and H. Thunman, Experimental Investigation of Volatiles-Bed Contact in a 2-4 MWth Bubbling Bed Reactor of a Dual Fluidized Bed Gasifier. Energy \& Fuels, 2015.

40. Sette, E., et al., Measuring fuel mixing under industrial fluidized-bed conditions - A camera-probe based fuel tracking system. Applied Energy, 2016. 163: p. 304-312. 